\title{
Endogenous Glucagon-Like Peptide-1 Reduces Drinking Behavior and Is Differentially Engaged by Water and Food Intakes in Rats
}

\author{
Naomi J. McKay, Daniela L. Galante, and Derek Daniels \\ Behavioral Neuroscience Program, Department of Psychology, The State University of New York at Buffalo, Buffalo, New York
}

Glucagon-like peptide-1 (GLP-1) is produced in the ileum and the nucleus of the solitary tract. It is well known that GLP-1 controls food intake, but there is a growing literature indicating that GLP-1 also is involved in fluid intake. It is not known, however, if the observed effects are pharmacological or if endogenous GLP-1 and its receptor contribute to physiological fluid intake control. Accordingly, we blocked endogenous GLP-1 by application of a receptor antagonist and measured subsequent drinking. Furthermore, we measured changes in GLP-1-associated gene expression after water intake, and compared the effects of fluid intake to those caused by food intake. Rats injected with the antagonist exendin-9 (Ex-9) drank more fluid in response to either subcutaneous hypertonic saline or water deprivation with partial rehydration than did vehicle-treated rats. Analysis of licking behavior showed that Ex-9 increased fluid intake by increasing the number of licking bursts, without having an effect on the number of licks per burst, suggesting that endogenous GLP-1 suppresses fluid intake by influencing satiety. Subsequent experiments showed that water intake had a selective effect on central GLP-1related gene expression, unlike food intake, which affected both central and peripheral GLP-1. Although water and food intakes both affected central GLP-1-relevant gene expression, there were notable differences in the timing of the effect. These results show a novel role of the endogenous GLP-1 system in fluid intake, and indicate that elements of the GLP-1 system can be engaged separately by different forms of ingestive behavior.

Key words: fluid homeostasis; food intake; glucagon-like peptide-1; thirst; water intake

\section{Introduction}

Glucagon-like peptide-1 (GLP-1) is well known to play a role in the control of food intake (Tang-Christensen et al., 1996; Turton et al., 1996; Schick et al., 2003; Chelikani et al., 2005; Williams et al., 2009; Hayes et al., 2011), but its role in other ingestive behaviors has received considerably less attention. Previous studies have shown that GLP-1 reduces drinking behavior in rats and humans (Navarro et al., 1996; Tang-Christensen et al., 1996; Wang et al., 1998; Larsen et al., 2001; Gutzwiller et al., 2006; McKay et al., 2011; McKay and Daniels, 2013), but to the best of our knowledge, no study has focused on the role of endogenous GLP-1 in fluid intake or the effect that fluid intake has on the GLP-1 system. Likewise, our understanding of the relevant populations of GLP-1-producing cells remains incomplete.

\footnotetext{
Received Aug. 7, 2014; revised 0ct. 22, 2014; accepted 0ct. 26, 2014.

Author contributions: N.J.M. and D.D. designed research; N.J.M. and D.L.G. performed research; N.J.M. and D.D. analyzed data; N.J.M. and D.D. wrote the paper.

Funding was provided by National Institutes of Health (HL091911 to D.D.), an American Psychological Association dissertation award (N.J.M.), and the Mark Diamond Research Fund of the Graduate Student Association at the University at Buffalo (N.J.M.). Kim Plyler, Dr. Jessica Santollo, and Philip Whalen provided helpful technical support. The data were presented in abstract form at the annual meeting of the Society for the Study of Ingestive Behavior. The authors declare no competing financial interests.

Correspondence should be addressed to Derek Daniels, University at Buffalo, Psychology Department, B74 Park Hall, Buffalo, NY 14260. E-mail: danielsd@buffalo.edu.

DOI:10.1523/JNEUROSCI.3267-14.2014

Copyright $\odot 2014$ the authors $\quad 0270-6474 / 14 / 3416417-07 \$ 15.00 / 0$
}

GLP-1 is produced by two primary sources, the L-cells within the intestine and neurons in the hindbrain, mostly in the nucleus of the solitary tract (NTS; Jin et al., 1988; Mojsov et al., 1990; Larsen et al., 1997; Merchenthaler et al., 1999; Holst, 2007). Both of these populations have been implicated in the control of food intake. The presence of nutrients in the gut stimulates release of intestinal GLP-1 into circulation (Elliott et al., 1993; Orskov et al., 1996), whereas meal intake increases cFos in hindbrain GLP-1positive cells (Kreisler et al., 2014), and hypothalamic GLP-1, presumably of hindbrain origin, is decreased by fasting (Beak et al., 1998). Analogous studies focusing on fluid intake, however, have not been conducted.

The present experiments used two main approaches to address the open questions regarding the role of endogenous GLP-1 in the control of fluid intake and the engagement of the GLP-1 system by ingestive behaviors. First, we tested the effect of central administration of the GLP-1R antagonist, exendin-9 (Ex-9), on water and saline intakes to test the hypothesis that endogenous GLP-1 controls stimulated fluid intake. Second, we examined the effect of water deprivation, with and without subsequent intake, on circulating GLP-1, and on expression of the GLP-1 precursor protein, proglucagon, and GLP-1R in the ileum and NTS to test the hypothesis that perturbations of fluid intake affect endogenous GLP-1. Moreover, a subset of the experiments focusing on fluid intake was conducted in parallel with experiments that focused on food intake to provide an evaluation of the specificity of 
the response for either fluid or food intakes. Generally, the results support a role of endogenous GLP-1 in the control of fluid intake and indicate that fluid and food intakes differentially engage the GLP-1 system.

\section{Materials and Methods}

Animals

Adult male Sprague Dawley rats (325-349 g) were purchased from Harlan Laboratories. Rats were housed in stainless steel wire mesh cages (Unifab) in a temperature- and humidity-controlled room and maintained on a $12 \mathrm{~h}$ light/dark cycle. Animals were given ad libitum access to standard rodent chow and water except where noted. All experimental protocols were approved by the Institutional Animal Care and Use Committee of the State University of New York at Buffalo, and the handling and care of animals was in accordance with the National Institutes of Health Guide for the Care and Use of Laboratory Animals.

\section{Cannula implantation and placement verification}

Rats in Experiments 1 and 2 were implanted with a chronic indwelling cannula aimed at the lateral ventricle (LV). Subjects were anesthetized with an intramuscular injection of ketamine $(70 \mathrm{mg} / \mathrm{kg}$; Fort Dodge Animal Health) and xylazine (5 mg/kg; Lloyd Laboratories) before being secured in a stereotaxic apparatus and receiving a subcutaneous injection of carprofen ( $5 \mathrm{mg} / \mathrm{kg}$; Pfizer Animal Health). A small burr hole was made in the skull and a guide cannula (26 gauge; Plastics One) was lowered to $0.9 \mathrm{~mm}$ posterior and $1.4 \mathrm{~mm}$ lateral to bregma, and $1.8 \mathrm{~mm}$ ventral to dura. The guide cannula was secured using bone screws and dental cement. Cannula placement was verified a minimum of $5 \mathrm{~d}$ after surgery by testing the drinking response to an injection of angiotensin II (10 ng). Rats that drank a minimum of $6 \mathrm{ml}$ of water were included in the experiments.

\section{Drug injections and intake measures}

Injections were made with a 33 gauge injection cannula that was connected to a $2 \mu \mathrm{l}$ Hamilton syringe via flexible PE-50 tubing. Injection cannulae were held in place for $\sim 30 \mathrm{~s}$ after each injection. Water and saline bottles were weighed immediately before and after testing periods. Total fluid intake was calculated by taking the difference of the pre- and post-bottle weights. Licking behavior was recorded using a contact lickometer (designed and constructed by the University of Pennsylvania Psychology Electronics Shop). The lickometer interfaced with a computer using an integrated USB digital I/O device (National Instruments) and data were acquired and processed in a MATLAB (The MathWorks) software environment. Bottle spouts were behind an electrically isolated metal plate with a $3.175 \mathrm{~mm}$ wide opening through which the rat needed to lick to reach the spout, minimizing the possibility of nontongue contact with the spout. Rats were habituated to the modified bottle arrangement for at least $5 \mathrm{~d}$.

\section{Blood and tissue collection}

Rats were anesthetized with isoflurane (Piramal Critical Care) for $90 \mathrm{~s}$, decapitated, and blood and tissue samples were collected immediately. Trunk blood was collected in a $4 \mathrm{ml} \mathrm{K2}$ ETDA $7.2 \mathrm{mg}$ vial with aprotinin $(500 \mathrm{kIU} / \mathrm{ml})$ and diprotin $\mathrm{A}(34 \mu \mathrm{g} / \mathrm{ml})$ and centrifuged at $1300 \mathrm{~g}$ for 10 min. Plasma was stored at $-80^{\circ} \mathrm{C}$ until GLP-1 content was measured by ELISA (ALPCO). Samples of ileum consisted of the centimeter of intestine before the ileocecal junction. Ileum samples were removed, cut lengthwise, and rinsed with PBS. While ileum samples were collected, another investigator simultaneously removed the brain and all tissue samples were flash frozen in 2-methylbutane on dry ice and stored at $-80^{\circ} \mathrm{C}$.

\section{$q P C R$}

NTS samples were taken by cutting the tissue into $300 \mu \mathrm{m}$ sections before $2 \mathrm{~mm}$ bilateral punches were taken, which included the NTS at the level of the area postrema. Real-time qPCR was used to assess proglucagon and GLP-1R mRNA in the ileum and NTS. Purified RNA, including a deoxyribonuclease step (MicroElute Total RNA Kit; Omega Bio-Tek) was used to prepare cDNA (iScript cDNA synthesis kit; Bio-Rad). qPCR was performed on $1000 \mathrm{ng}$ of RNA from the NTS and $3000 \mathrm{ng}$ of RNA from the ileum with an iCycler (Bio-Rad) using iQ SYBR Green Supermix (Bio-Rad) according to the manufacturer's instructions. Primer sequences were as follows: proglucagon sense, $5^{\prime}$-ACCGCCCTGAGATTACTTTTCTG-3', antisense, 5' -AGTTCTCTTTCCAGGTTCACCAC3', GLP-1R sense, 5' -CCGGGTCATCTGCATCGT-3', antisense, 5' -AG TCTGCATTTGATGTCGGTCTT-3', GAPDH sense, 5' -AACGACC CCTTCATTGAC-3', antisense, 5' -TCCACGACATACTCAGCAC-3', $18 \mathrm{~S}$ sense, 5' -CACGGGTGACGGGGAATCAG-3', antisense, 5' -CCGG TCGGGAGTGGGTAATTTG-3'.

\section{Experimental designs}

Experiment 1: effect of LV Ex-9 on the drinking response to subcutaneous hypertonic saline. Approximately $2 \mathrm{~h}$ after lights on, food and water were removed and experimentally naive rats $(n=11)$ received an injection of Ex-9 (100 $\mu \mathrm{g}$ in $2 \mu \mathrm{l}$; dose based on work by Turton et al., 1996; Meeran et al., 1999) or vehicle $(0.9 \% \mathrm{NaCl})$ into the $\mathrm{LV}$ immediately before a subcutaneous injection of $2 \%$ lidocaine $(0.1 \mathrm{ml})$ followed by hypertonic saline $(2 \mathrm{ml} / \mathrm{kg}$ body wt; $1 \mathrm{M} \mathrm{NaCl}$ ) or a control injection $(2 \mathrm{ml} / \mathrm{kg}$ body wt; $0.9 \% \mathrm{NaCl}$ ). Water, but not food, was returned $30 \mathrm{~min}$ after the subcutaneous injection of hypertonic saline. Drinking behavior was recorded for $2 \mathrm{~h}$. A repeated-measures design was used with each rat acting as its own control. There were at least $4 \mathrm{~d}$ between experimental days, and order of treatment was counterbalanced.

A separate group of rats, naive to the experimental conditions, was implanted with LV cannulae. At least $5 \mathrm{~d}$ after verification of proper cannula placement, rats were either given an LV injection of vehicle $(2 \mu \mathrm{l}$ $0.9 \% \mathrm{NaCl}$ ) or uninjected immediately before rats in both groups received a subcutaneous injection of $2 \%$ lidocaine $(0.1 \mathrm{ml})$ followed by hypertonic saline ( $2 \mathrm{ml} / \mathrm{kg}$ body wt; $1 \mathrm{M} \mathrm{NaCl} ; n=6)$. A counterbalanced repeated-measures design was used so that all rats were included in both vehicle-injection and uninjected conditions.

Experiment 2: effect of LV Ex-9 on the drinking response to water deprivation-partial rehydration. Experiment 1 was designed to test for effects of the GLP-1R antagonist on water intake and, therefore, used a stimulus that more selectively increases water intake. To test for an effect of Ex- 9 on saline intake, we used a water deprivation-partial rehydration (WD-PR) paradigm similar to those used previously (Sato et al., 1996; McKay and Daniels, 2013). To this end, experimentally naive rats $(n=$ 15) were habituated to ad libitum access to both water and $1.5 \% \mathrm{NaCl}$ for a minimum of $7 \mathrm{~d}$ before testing. Approximately $2 \mathrm{~h}$ after lights on, fluids were removed from half the rats, and remained unavailable for $24 \mathrm{~h}$. On test day, food was removed, and water was returned for $90 \mathrm{~min}$. Rats were then given an LV injection of Ex-9 (100 $\mu \mathrm{g}$ in $2 \mu \mathrm{l})$ or vehicle $(0.9 \%$ $\mathrm{NaCl}$ ). Access to water and $1.5 \%$ saline was allowed 30 min after the LV injection and drinking behavior was measured for $2 \mathrm{~h}$. A repeatedmeasures design was used with each rat acting as its own control. There were at least $4 \mathrm{~d}$ between experimental days, and order of treatment was counterbalanced.

Experiment 3: effect of water deprivation with and without subsequent water intake on circulating GLP-1. Beginning $\sim 1 \mathrm{~h}$ before lights off, subjects were deprived of water for $24 \mathrm{~h}$, after which food was removed and rats were given access to water for $0 \mathrm{~min}, 10 \mathrm{~min}$, or $30 \mathrm{~min}$ before blood collection. A separate control group was not water deprived before blood collection. Trunk blood was collected and plasma GLP-1 was analyzed (see above, Blood and tissue collection).

To assess whether circulating GLP-1 was similar after water or food intake, we examined the effect of nutrient intake after food deprivation on plasma GLP-1. This experiment was conducted in two separate groups of rats. Group 1 was given a pre-exposure to Ensure nutrition shake (original vanilla) $\sim 3 \mathrm{~d}$ before the start of the experiment. Rats in Group 2 were exposed to one cycle of $24 \mathrm{~h}$ food deprivation followed by access to Ensure immediately before lights out. A minimum of $3 \mathrm{~d}$ later, rats in both groups were food deprived for $24 \mathrm{~h}$ (beginning $\sim 1 \mathrm{~h}$ before lights off), and then given access to Ensure for $0 \mathrm{~min}$ or $30 \mathrm{~min}$ before blood collection. Trunk blood was collected and GLP-1 content in plasma was analyzed (see above, Blood and tissue collection). Rats in this experiment had been used in unrelated pilot experiments no less than 1 week before Experiment 3 began. 


\section{Isotonic - Hypertonic}
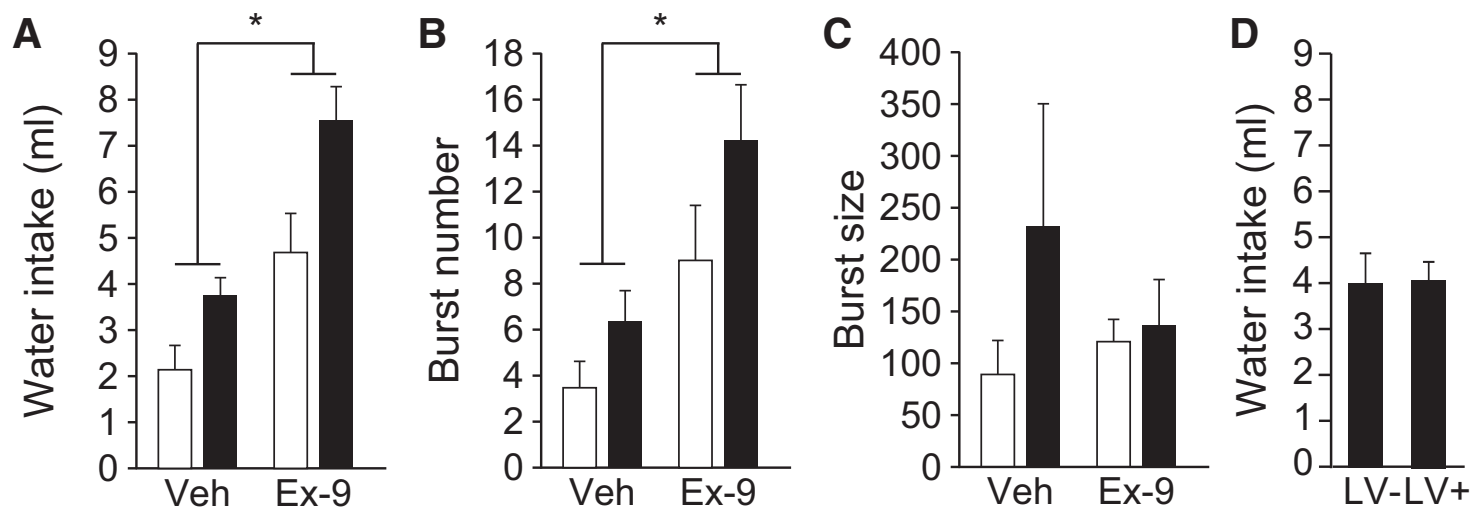

Figure 1. Effect of Ex-9 on water intake stimulated by hypertonic saline. Rats ( $n=11$ ) received a subcutaneous injection of isotonic saline (white bars) or hypertonic saline (black bars), before an LV injection of vehicle or Ex-9. A repeated-measures design was used so that all rats received all four treatment conditions, in balanced order, with at least $4 \mathrm{~d}$ between treatments. $\boldsymbol{A}$, Treatment with Ex-9 increased total water intake during the $2 \mathrm{~h}$ test in all rats regardless of saline treatment. $\boldsymbol{B}$, Treatment with Ex-9 increased the number of licking bursts during the $2 \mathrm{~h}$ test. $\boldsymbol{C}$, Treatment with Ex-9 had no effect on the number of licks per burst. $D$, An LV injection of vehicle (Veh) did not affect fluid intake in rats given subcutaneous hypertonic saline. Asterisks indicate a main effect of Ex- 9 versus vehicle $(p<0.05)$.

Experiment 4: effect of water or food deprivation with and without subsequent intake on proglucagon and GLP-1R $m R N A$. Rats were water deprived for $24 \mathrm{~h}$, after which food was removed and water was made available for $0 \mathrm{~h}, 0.5 \mathrm{~h}, 1.5 \mathrm{~h}$, or $4 \mathrm{~h}$ before tissue collection. Additional rats were deprived of food for $24 \mathrm{~h}$, after which standard chow was made available for $0 \mathrm{~h}, 1.5 \mathrm{~h}$, or $4 \mathrm{~h}$ before tissue collection, and water remained available during this time. A separate group of rats was not water or food deprived before tissue collection and was used as a control for separate analyses for the water and food studies. All rats were decapitated and tissue was removed and processed for proglucagon and GLP-1R mRNA (see above sections, Blood and tissue collection and qPCR). One outlier, defined as $>2$ SDs away from the mean, was removed from the $1.5 \mathrm{~h} \mathrm{NTS}$ proglucagon water-access group, the $4 \mathrm{~h}$ NTS proglucagon food-access group, and one from the $4 \mathrm{~h}$ ileum proglucagon food-access group. Rats in this experiment had been used in unrelated pilot experiments no less than 1 week before Experiment 4 began.

\section{Data analysis}

Total fluid intake in Experiments 1 and 2 was calculated as the pretest bottle weight minus the post-test bottle weight. For analysis of licking behavior, a burst was defined as a group of at least two licks with a maximum interlick interval of $1 \mathrm{~s}$ (burst criteria was based on Spector et al., 1998). Subjects that did not have at least one burst were included in the analysis of burst number, but excluded from the analysis of burst size. qPCR data for each subject was calculated by the $\Delta \Delta C T$ quantification method and normalized to the expression of a housekeeping gene. NTS samples were normalized to GAPDH and ileum samples were normalized to 18S. All conditions then were expressed as a percentage of control. Hypothesis testing was performed using Statistica (StatSoft). Two-way repeated-measures, ANOVA, one-way ANOVA, or Student's $t$ tests were used as appropriate. Statistically significant effects $(p<0.05)$ were further analyzed using Newman-Keuls post hoc tests.

\section{Results}

Experiment 1: effect of LV Ex-9 on the drinking response to subcutaneous hypertonic saline

Previous studies showed that GLP-1R activation decreases water intake (McKay et al., 2011; McKay and Daniels, 2013). To test for a role of endogenous GLP-1 in the response to a dipsogenic challenge, we gave injections of the GLP-1R antagonist, Ex-9, or vehicle to rats that were stimulated to drink by injection of hypertonic saline. LV injection of Ex-9 increased water intake regardless of saline condition $(n=11)$. Analysis of total water intake revealed a main effect of LV Drug (Fig. $1 A ; F_{(1,10)}=33.53$, $p=0.0002$ ), as well as a main effect of Subcutaneous Saline $\left(F_{(1,10)}=60.28, p=0.00002\right)$ indicating that Ex-9 or SC hypertonic saline each increased drinking. We did not, however, find a statistically significant interaction $\left(F_{(1,10)}=1.07, p=0.33\right)$.

To evaluate the behavioral differences that corresponded to the changes in intake, we analyzed drinking microstructure. Analysis with ANOVA found a main effect of LV Drug $\left(F_{(1,10)}=18.67, p=0.002\right)$ and a main effect of Subcutaneous Saline $\left(F_{(1,10)}=8.31, p=0.02\right)$ on burst number (Fig. $\left.1 B\right)$. In contrast, there was no reliable effect of LV or subcutaneous treatment on burst size (Fig. $1 C ; F_{(1,6)}=0.41, p=0.55 ; F_{(1,6)}=1.88$, $p=0.22$, respectively)

It has been proposed that the actions of GLP-1R blockade are at least partially mediated by removal or attenuation of an intakesuppressing stress response (Maniscalco et al., 2012). This hypothesis requires that the experimental conditions alone (e.g., the injection) suppress intake. Accordingly, we tested for any stressinduced hypodipsia resulting from the LV injection in the paradigm used in Experiment 1 by comparing the drinking response in subjects given an injection of vehicle into the LV to rats given no injections $(n=6)$. We found no effect of the LV injection on fluid intake ( $p=0.95$; Fig. $1 D)$.

\section{Experiment 2: effect of LV Ex-9 on the drinking response to WD-PR}

To test the hypothesis that the effect of Ex-9 observed in Experiment 1 extends to saline intake, we used injections of Ex-9 in a WD-PR test $(n=15)$. Similar to the findings in Experiment 1 , injections of Ex-9 increased both water and saline intakes regardless of condition (Fig. 2A). Repeated-measures ANOVA on saline intake revealed significant main effects of LV Drug $\left(F_{(1,14)}=\right.$ 34.04, $p=0.00004)$ and Fluid Status $\left(F_{(1,14)}=35.03, p=\right.$ $0.00004)$, without a statistically significant interaction. Although the WD-PR protocol produces only a small amount of water intake during the testing period, and is therefore not the main focus of this procedure, data analysis revealed main effects of $\mathrm{LV}$ $\operatorname{Drug}\left(F_{(1,114)}=71.58, p=0.000001\right)$ and Fluid Status $\left(F_{(1,14)}=\right.$ $5.92, p=0.03$ ) on water intake during the test (Fig. $2 B$ ), indicating that Ex-9 increased water intake in both deprived and nondeprived rats. 


\section{No Deprivation}

Water Deprivation

A

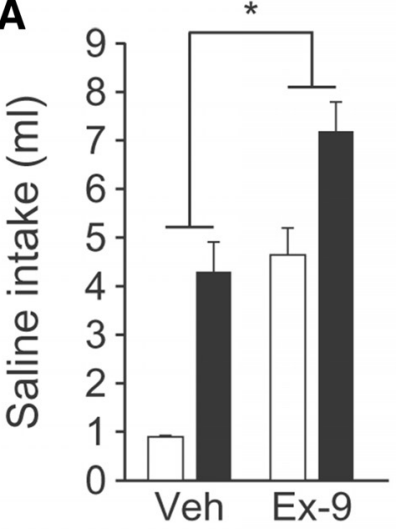

B
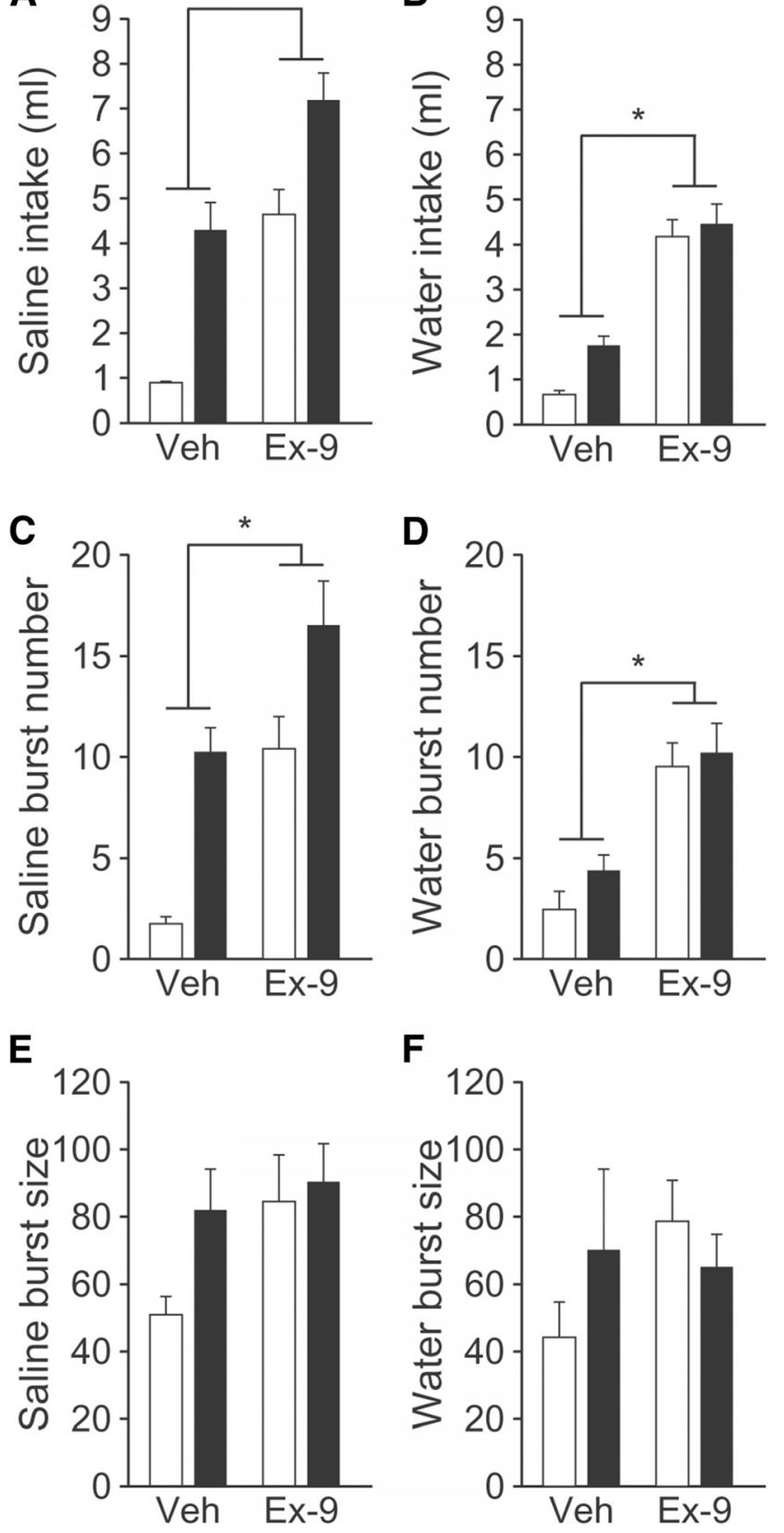

$\mathbf{F}$

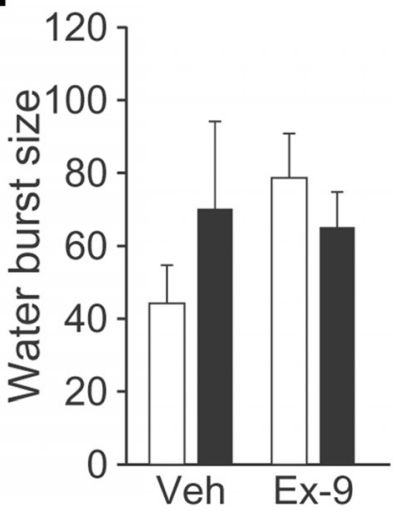

Figure 2. Effect of Ex-9 on water and saline intakes stimulated by WD-PR. Rats ( $n=15$ ) were fluid deprived for $24 \mathrm{~h}$ (black bars) or were not fluid deprived (white bars), before $1.5 \mathrm{~h}$ access to water. Rats then were given an LV injection of vehicle or Ex-9 30 min before a twobottle intake test of $1.5 \%$ saline and water. A repeated-measures design was used so that all rats received all four treatment conditions, in balanced order, with at least $4 \mathrm{~d}$ between treatments. Ex-9 increased total saline $(\boldsymbol{A})$ and water $(\boldsymbol{B})$ intakes during the $2 \mathrm{~h}$ test in all rats regardless of water deprivation condition. Ex-9 increased the number of licking bursts for saline $(\boldsymbol{C})$ and water $(\boldsymbol{D})$ during the $2 \mathrm{~h}$ test. Ex-9 had no effect on the number of licks per burst for saline $(\boldsymbol{E})$ or for water $(\boldsymbol{F})$. Asterisks indicate a main effect of Ex-9 versus vehicle $($ Veh; $p<0.05)$.

To determine whether a change in burst number or burst size mediated the increased saline intake, lick patterns were analyzed and revealed an effect consistent with the findings of Experiment 1(Fig. 2C,D). Specifically, repeated-measures ANOVA revealed main effects of LV Drug $\left(F_{(1,14)}=14.92, p=0.002\right)$ and Fluid Status $\left(F_{(1,14)}=33.38, p=0.00005\right)$ on burst number with no

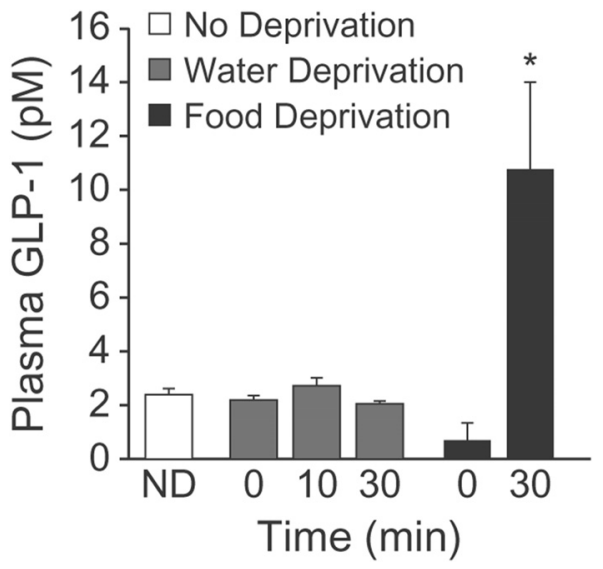

Figure 3. Effect of water and food intakes on circulating GLP-1. Rats ( $n=6-7$ per group) were deprived of water (gray bars) or food (black bars) for $24 \mathrm{~h}$, or were not deprived (ND; white bar). Trunk blood was collected immediately after the deprivation period ( $0 \mathrm{~min}$ ) or after subsequent access to water (10 min or $30 \mathrm{~min}$; water-deprived rats) or food ( $30 \mathrm{~min}$; food-deprived rats). There was no observed change in plasma GLP-1 after water deprivation or water intake, but there was an increase after food intake. Asterisks indicate difference from food deprived $(p<0.05)$.

reliable effect of either Ex-9 or water deprivation on saline burst size. The results were similar when licking for water was analyzed. Specifically, we found a main effect of LV Drug on burst number (Fig. $2 E, F ; F_{(1,14)}=42.76, p=0.00001$ ). There was, however, no effect of Fluid Status on number of bursts for water $\left(F_{(1,14)}=\right.$ $2.02, p=0.18)$. Consistent with the findings above and in previous studies (McKay and Daniels, 2013), we found no effect of LV Drug $\left(F_{(1,8)}=1.01, p=0.35\right)$ or Fluid Status $\left(F_{(1,8)}=0.19, p=\right.$ $0.68)$ on the number of licks per burst.

Experiment 3: effect of water deprivation with and without subsequent water intake on circulating GLP-1

The experiments above demonstrate that blockade of GLP-1R increases fluid intake, but whether or not changes in GLP-1 occur with alterations of fluid state remained an open question. There was no effect of water deprivation with or without water intake on plasma GLP-1 (Fig. $3 ; F_{(3,19)}=1.31, p=0.3 ; n=6-7$ per group).

To provide a measure of comparison, we repeated the experiment using food-deprived and re-fed rats $(n=11-12$ per group). As described in Materials and Methods, we used two modestly different approaches. The results did not depend on the approach and the data were, therefore, combined for subsequent analysis. Rats that had access to food had greater levels of plasma GLP-1 than did rats in the deprived group (Fig. $3 ; p=0.005$ ).

Experiment 4: effect of water or food deprivation with and without subsequent intake on proglucagon and GLP-1R mRNA

The present results show that central administration of Ex-9 increased fluid intake, and that circulating GLP-1 was unaffected by manipulations of body fluid homeostasis, suggesting a central component in the control of water intake by GLP-1. We found that water deprivation alone did not alter proglucagon mRNA levels, but that proglucagon mRNA was significantly elevated $4 \mathrm{~h}$ after water-deprived rats were allowed to drink (Fig. $4 A ; F_{(4,23)}=$ 4.74, $p=0.006 ; n=5-6$ per group). We found no similar changes in proglucagon mRNA in the ileum or in GLP-1R mRNA in either the NTS or ileum (Fig. $4 B-D ; F_{(3,20)}=2.82, p=0.07$; $F_{(3,19)}=1.1, p=0.38 ; F_{(3,21)}=1.66, p=0.21$, respectively $)$. 

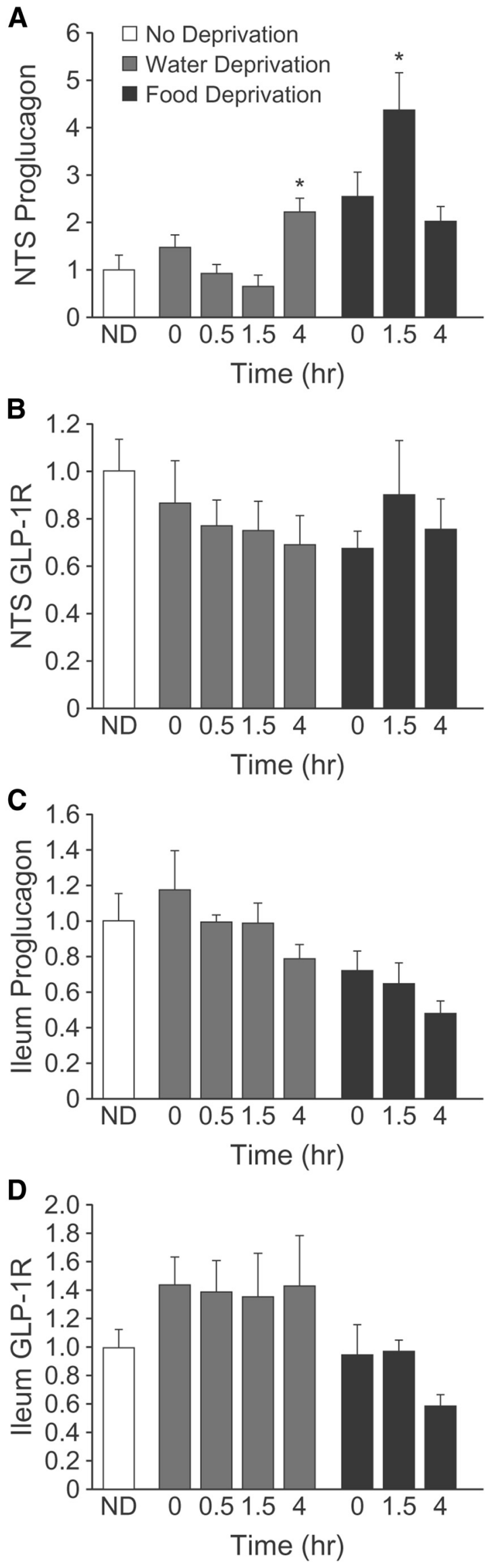

To see if water and food similarly engage the GLP-1 system, additional rats were food deprived and allowed or not allowed to re-feed. Similar to the effect of water intake, we found that food intake after deprivation caused an elevation of proglucagon in the NTS, but had no effect on GLP-1R. ANOVA revealed a significant effect on proglucagon mRNA in the NTS and post hoc analyses showed that unlike after water intake, the increased proglucagon mRNA occurred $1.5 \mathrm{~h}$ after food was returned and was no longer elevated by $4 \mathrm{~h}\left(F_{(3,18)}=7.29, p=0.002\right.$; Student-NewmanKeuls post hoc). Also similar to the effect of water intake, there was no effect of Food Intake on GLP-1R in the NTS $\left(F_{(3,19)}=1.1, p=\right.$ $0.38)$ or on proglucagon $\left(F_{(2,16)}=0.51, p=0.61\right)$ or GLP-1R $\left(F_{(2,16)}=1.88, p=0.18\right)$ in the ileum.

\section{Discussion}

The GLP-1 system has been intensely studied recently for its role in energy homeostasis. It is, however, involved in other motivated behaviors including fluid and drug intakes (Navarro et al., 1996; Tang-Christensen et al., 1996; McKay et al., 2011; McKay and Daniels, 2013; Egecioglu et al., 2013a, b). The precise role played by GLP-1 in these behaviors remains unclear, and whether the various behavioral effects are mediated separately remains an important open question. The present experiments generated the novel finding that the endogenous GLP-1 system is involved in the regulation of fluid intake, and highlights novel differences and similarities between the roles in fluid and food intakes. Specifically, administration of a GLP-1R antagonist increased fluid intake in dipsogenic and nondipsetic conditions, strongly suggesting that endogenous GLP-1 tone is maintained to suppress drinking both during times of elevated intake and during low intake. Moreover, we found that deprivation and subsequent intake increased proglucagon mRNA in the NTS, although water deprivation alone had no effect on the GLP-1 system, suggesting that the general tone of the GLP-1 system does not change as a function of motivation, but is altered upon consumption.

There are several notable comparisons to be made between the effects of water and food intakes on the GLP-1 system. Consumption of either water or food increased proglucagon mRNA in the NTS, suggesting that either form of ingestive behavior stimulates hindbrain GLP-1 production. We found no change, however, in GLP-1R mRNA in either the feeding or drinking experiment, indicating that the change in GLP-1 mRNA is not accompanied by a change in expression of the receptor in the same brain area. This means either that activation of the local receptor populations does not, in these cases, lead to changes in receptor expression, or that the changes occur in other regions. The similarities between the feeding and drinking conditions suggest at least some overlap in the circuits involved in the behaviors, but differences in the responses suggest that the overlap, if any, is incomplete. In contrast to the effect of fluid intake, which was isolated to the NTS, food intake increased both circulating GLP-1 and NTS proglucagon mRNA, indicating that food intake stimulates both

$\leftarrow$

Figure 4. Effect of water and food intake on proglucagon and GLP-1R mRNA in the NTS and ileum. Rats ( $n=5-6$ per group) were deprived of water (gray bars) or food (black bars) for $24 \mathrm{~h}$, or were not deprived (white bar). Brains were removed immediately after the deprivation period ( $0 \mathrm{~min}$ ) or after subsequent access to water ( $0.5 \mathrm{~h}, 1.5 \mathrm{~h}$, or $4 \mathrm{~h}$; water-deprived rats) or food (1.5 h or $4 \mathrm{~h}$; food-deprived rats). Proglucagon mRNA in the NTS was elevated $4 \mathrm{~h}$ after access to water, whereas proglucagon mRNA in the NTS was elevated $1.5 \mathrm{~h}$ after access to food $(\boldsymbol{A})$. There was no effect of water or food intake on GLP-1R mRNA in the NTS $(\boldsymbol{B})$, proglucagon mRNA in the ileum $(\boldsymbol{C})$, or GLP-1R mRNA in the ileum $(\boldsymbol{D})$. Asterisks indicate difference from non-deprived $(p<0.05)$. 
peripheral and central GLP-1, whereas water intake stimulates only central GLP-1. Furthermore, although food and water intakes elevated NTS proglucagon mRNA, the timing of the effects was different. Specifically, the observed increase occurred $4 \mathrm{~h}$ after water intake, whereas food intake caused a more rapid effect that was seen $1.5 \mathrm{~h}$ after consumption. The dissimilar timing may be related to the elevation of circulating GLP-1 levels after food intake, or may reflect differences in the route by which drinkingand feeding-related signals reach the brain. Nevertheless, the differences in the response, both in the location and in the timing, reveal novel separable elements of the GLP-1 system.

The present findings add to our understanding of the role of GLP-1 in the control of fluid intake by providing evidence that endogenous GLP-1 is involved in drinking termination. In support of this, lick analysis found that blockade of GLP-1R increased the number of bursts, but did not affect burst size, suggesting that under normal circumstances GLP-1 acts to suppress fluid intake by maintaining satiety (Spector et al., 1998; Smith, 2001). This suggestion is further supported by our previous studies showing that activation of the GLP-1R selectively suppresses burst number (McKay and Daniels, 2013). Furthermore, there was no effect of water deprivation alone on proglucagon expression, and it was only when water was consumed that we saw increased production of GLP-1 mRNA, suggesting that GLP-1 is released upon consumption, thereby preventing further intake.

Several technical issues need to be considered before drawing conclusions about the intake effects of GLP-1. First, the stimulation of intake by Ex-9 may, as we postulate, reflect a reduction in the overall GLP-1 tone, or it may be due to inverse agonist-like properties of Ex-9. Specifically, basal activity of GLP-1R is suppressed by Ex-9 in the absence of GLP-1 (Serre et al., 1998). Accordingly, it is possible that altered behavior after Ex-9 is independent of any endogenous GLP-1 tone. Second, although we found no change in plasma GLP-1 levels after manipulations in water intake, a small magnitude effect could have been obscured by rapid degradation of GLP-1 in circulation (Holst and Deacon, 2005). The present studies clearly demonstrate, however, that any effect of water intake on peripheral GLP-1 is at least markedly less than the analogous effect of food intake. Third, our measures of proglucagon mRNA are used as a proxy for levels of GLP-1, and may not faithfully represent a similar increase, in direction or magnitude, of GLP-1. The region of the NTS sampled, however, is known to contain GLP-1-producing cells (Jin et al., 1988) and previous studies show a positive correlation between NTS proglucagon mRNA and central GLP-1 (Goldstone et al., 2000). Therefore, it is likely that the observed increase in proglucagon after water intake reflects a similar elevation of GLP-1. Fourth, given the observed increase in circulating GLP-1, we were surprised by the lack of a concomitant change in proglucagon mRNA in the ileum. We, however, urge caution before using the results of these studies to conclude that food deprivation with re-feeding does not affect GLP-1 production in the ileum because the relatively small sample sizes here could have impeded detection of subtle effects. Indeed, other groups have reported an effect of energy balance on proglucagon in the ileum (Cani et al., 2007; Lu et al., 2009; Yu et al., 2009). These other studies, however, used chronic dietary manipulation, which may have different effects than the acute intake used in the present studies. Finally, we observed what appeared to be an increase in NTS proglucagon mRNA when rats were food deprived, but not allowed to eat. This difference was not statistically significant, but we urge the same caution prescribed above given the relatively small sample sizes used in the experiment. The focus of our research is on the fluid intake relevance of the GLP-1 system, but we imagine that the hint of a difference may guide future studies by investigators more focused on food intake. These caveats notwithstanding, the results strongly support a role of the GLP-1 system in the control of fluid balance.

The precise means by which GLP-1 affects intake remains unclear, and future studies are needed to address this important issue. Our analyses of drinking microstructure provide some insight by showing that the fluid intake effects are more consistent with a role in satiety than with a role in altered hedonic value of the water and saline. It has been proposed that GLP-1 acts via a stress-induced reduction of intake, and that any increase in intake after GLP-1R blockade more directly reflects a decrease in the stress response to the injection itself (Maniscalco et al., 2012). The present results, however, argue against this hypothesis, at least with respect to fluid intake, because the central injection itself did not decrease water intake. Furthermore, the findings suggest that the LV injection itself is not, in fact, a stressor because previous studies of stress and fluid intake found that either mild or severe stressors increase, rather than decrease, fluid intake (Deaux and Kakolewski, 1970; Vaswani et al., 1983; Bourjeili et al., 1995). This does not discount a role of GLP-1 in stress, but it does suggest that any effect of GLP-1 on stress is separate from its effects on fluid intake.

In addition to a contribution of the stress response, it is also important to consider blood pressure effects on the interactions between ingestive behavior and the GLP-1 system. Indeed, increased blood pressure decreases water intake (Robinson and Evered, 1987), and GLP-1R agonists stimulate a pressure response (Yamamoto et al., 2002). Subtle differences in the ingestive and pressor responses to GLP-1R agonists, however, could argue against the idea that blood pressure is the critical factor connecting ingestion and the GLP-1 system. Specifically, after a similar dose of exendin-4, water intake is suppressed for an extended period of time, but the pressor effects are more limited in duration (Gardiner et al., 2006; McKay et al., 2011). Therefore, it seems unlikely that any pressor effect is entirely responsible for the observed intake effects. Nevertheless, future studies are needed to determine the precise role that blood pressure may have in the observed effects.

In summary, we report, for the first time, that the endogenous GLP-1 system is involved in fluid intake control, and that GLP1-producing cells in the NTS may be responsible for these effects. Furthermore, the behavioral differences likely reflect a satiating effect of endogenous GLP-1. Accordingly, this work contributes to the growing literature demonstrating that the GLP-1 system influences multiple consummatory behaviors. Perhaps most important for the development of future studies, we show that the GLP-1 system has separate elements that can be differentially engaged by water and food intakes.

\section{References}

Beak SA, Heath MM, Small CJ, Morgan DG, Ghatei MA, Taylor AD, Buckingham JC, Bloom SR, Smith DM (1998) Glucagon-like peptide-1 stimulates luteinizing hormone-releasing hormone secretion in a rodent hypothalamic neuronal cell line. J Clin Invest 101:1334-1341. CrossRef Medline

Bourjeili N, Turner M, Stinner J, Ely D (1995) Sympathetic nervous system influences salt appetite in four strains of rats. Physiol Behav 58:437-443. CrossRef Medline

Cani PD, Hoste S, Guiot Y, Delzenne NM (2007) Dietary non-digestible carbohydrates promote L-cell differentiation in the proximal colon of rats. Br J Nutr 98:32-37. CrossRef Medline

Chelikani PK, Haver AC, Reidelberger RD (2005) Intravenous infusion of glucagon-like peptide-1 potently inhibits food intake, sham feeding, and gastric emptying in rats. Am J Physiol Regul Integr Comp Physiol 288: R1695-R1706. CrossRef Medline 
Deaux E, Kakolewski JW (1970) Emotionally induced increases in effective osmotic pressure and subsequent thirst. Science 169:1226-1228. CrossRef Medline

Egecioglu E, Engel JA, Jerlhag E (2013a) The glucagon-like peptide 1 analogue Exendin- 4 attenuates the nicotine-induced locomotor stimulation, accumbal dopamine release, conditioned place preference as well as the expression of locomotor sensitization in mice. PLoS One 8:e77284. CrossRef Medline

Egecioglu E, Steensland P, Fredriksson I, Feltmann K, Engel JA, Jerlhag E (2013b) The glucagon-like peptide 1 analogue Exendin-4 attenuates alcohol mediated behaviors in rodents. Psychoneuroendocrinology 38: 1259-1270. CrossRef Medline

Elliott RM, Morgan LM, Tredger JA, Deacon S, Wright J, Marks V (1993) Glucagon-like peptide-1 (7-36)amide and glucose-dependent insulinotropic polypeptide secretion in response to nutrient ingestion in man: acute post-prandial and 24-h secretion patterns. J Endocrinol 138:159166. CrossRef Medline

Gardiner SM, March JE, Kemp PA, Bennett T (2006) Mesenteric vasoconstriction and hindquarters vasodilatation accompany the pressor actions of exendin-4 in conscious rats. J Pharmacol Exp Ther 316:852-859. CrossRef Medline

Goldstone AP, Morgan I, Mercer JG, Morgan DG, Moar KM, Ghatei MA, Bloom SR (2000) Effect of leptin on hypothalamic GLP-1 peptide and brain-stem pre-proglucagon mRNA. Biochem Biophys Res Commun 269:331-335. CrossRef Medline

Gutzwiller JP, Hruz P, Huber AR, Hamel C, Zehnder C, Drewe J, Gutmann H, Stanga Z, Vogel D, Beglinger C (2006) Glucagon-like peptide-1 is involved in sodium and water homeostasis in humans. Digestion 73:142150. CrossRef Medline

Hayes MR, Kanoski SE, Alhadeff AL, Grill HJ (2011) Comparative effects of the long-acting glp-1 receptor ligands, liraglutide and exendin- 4 , on food intake and body weight suppression in rats. Obesity 19:1342-1349. CrossRef Medline

Holst JJ (2007) The physiology of glucagon-like peptide 1. Physiol Rev 87: 1409-1439. CrossRef Medline

Holst JJ, Deacon CF (2005) Glucagon-like peptide-1 mediates the therapeutic actions of DPP-IV inhibitors. Diabetologia 48:612-615. CrossRef Medline

Jin SL, Han VK, Simmons JG, Towle AC, Lauder JM, Lund PK (1988) Distribution of glucagonlike peptide I (GLP-I), glucagon, and glicentin in the rat brain: an immunocytochemical study. J Comp Neurol 271:519-532. CrossRef Medline

Kreisler AD, Davis EA, Rinaman L (2014) Differential activation of chemically identified neurons in the caudal nucleus of the solitary tract in nonentrained rats after intake of satiating vs. non-satiating meals. Physiol Behav S0031-9384(14)00032-8. CrossRef Medline

Larsen PJ, Tang-Christensen M, Holst JJ, Orskov C (1997) Distribution of glucagon-like peptide-1 and other preproglucagon-derived peptides in the rat hypothalamus and brainstem. Neuroscience 77:257-270. CrossRef Medline

Larsen PJ, Fledelius C, Knudsen LB, Tang-Christensen M (2001) Systemic administration of the long-acting GLP-1 derivative NN2211 induces lasting and reversible weight loss in both normal and obese rats. Diabetes 50:2530-2539. CrossRef Medline

Lu SS, Yu YL, Zhu HJ, Liu XD, Liu L, Liu YW, Wang P, Xie L, Wang GJ (2009) Berberine promotes glucagon-like peptide-1 (7-36) amide secretion in streptozotocin-induced diabetic rats. J Endocrinol 200:159-165. CrossRef Medline

Maniscalco JW, Kreisler AD, Rinaman L (2012) Satiation and stressinduced hypophagia: examining the role of hindbrain neurons expressing prolactin-releasing Peptide or glucagon-like peptide 1. Front Neurosci 6:199. CrossRef Medline

McKay NJ, Daniels D (2013) Glucagon-like Peptide-1 receptor agonist administration suppresses both water and saline intake in rats. J Neuroendocrinol 25:929-938. CrossRef Medline

McKay NJ, Kanoski SE, Hayes MR, Daniels D (2011) Glucagon-like peptide-1 receptor agonists suppress water intake independent of effects on food intake. Am J Physiol Regul Integr Comp Physiol 301:R1755R1764. CrossRef Medline
Meeran K, O'Shea D, Edwards CM, Turton MD, Heath MM, Gunn I, Abusnana S, Rossi M, Small CJ, Goldstone AP, Taylor GM, Sunter D, Steere J, Choi SJ, Ghatei MA, Bloom SR (1999) Repeated intracerebroventricular administration of glucagon-like peptide-1-(7-36) amide or exendin-(939) alters body weight in the rat. Endocrinology 140:244-250. CrossRef Medline

Merchenthaler I, Lane M, Shughrue P (1999) Distribution of pre-proglucagon and glucagon-like peptide-1 receptor messenger RNAs in the rat central nervous system. J Comp Neurol 403:261-280. CrossRef Medline

Mojsov S, Kopczynski MG, Habener JF (1990) Both amidated and nonamidated forms of glucagon-like peptide I are synthesized in the rat intestine and the pancreas. J Biol Chem 265:8001-8008. Medline

Navarro M, Rodriquez de Fonseca F, Alvarez E, Chowen JA, Zueco JA, Gomez R, Eng J, Blázquez E (1996) Colocalization of glucagon-like peptide-1 (GLP-1) receptors, glucose transporter GLUT-2, and glucokinase mRNAs in rat hypothalamic cells: evidence for a role of GLP-1 receptor agonists as an inhibitory signal for food and water intake. J Neurochem 67:1982-1991. CrossRef Medline

Orskov C, Wettergren A, Holst JJ (1996) Secretion of the incretin hormones glucagon-like peptide-1 and gastric inhibitory polypeptide correlates with insulin secretion in normal man throughout the day. Scand J Gastroenterol 31:665-670. CrossRef Medline

Robinson MM, Evered MD (1987) Pressor action of intravenous angiotensin II reduces drinking response in rats. Am J Physiol 252:R754-R759. Medline

Sato MA, Yada MM, De Luca LA Jr (1996) Antagonism of the reninangiotensin system and water deprivation-induced $\mathrm{NaCl}$ intake in rats. Physiol Behav 60:1099-1104. CrossRef Medline

Schick RR, Zimmermann JP, vorm Walde T, Schusdziarra V (2003) Peptides that regulate food intake: glucagon-like peptide 1-(7-36) amide acts at lateral and medial hypothalamic sites to suppress feeding in rats. Am J Physiol Regul Integr Comp Physiol 284:R1427-R1435. Medline

Serre V, Dolci W, Schaerer E, Scrocchi L, Drucker D, Efrat S, Thorens B (1998) Exendin-(9-39) is an inverse agonist of the murine glucagon-like peptide-1 receptor: implications for basal intracellular cyclic adenosine $3^{\prime}, 5^{\prime}$-monophosphate levels and beta-cell glucose competence. Endocrinology 139:4448-4454. CrossRef Medline

Smith GP (2001) John Davis and the meanings of licking. Appetite 36:84-92. CrossRef Medline

Spector AC, Klumpp PA, Kaplan JM (1998) Analytical issues in the evaluation of food deprivation and sucrose concentration effects on the microstructure of licking behavior in the rat. Behav Neurosci 112:678-694. CrossRef Medline

Tang-Christensen M, Larsen PJ, Göke R, Fink-Jensen A, Jessop DS, Møller M, Sheikh SP (1996) Central administration of GLP-1-(7-36) amide inhibits food and water intake in rats. Am J Physiol 271:R848-R856. Medline

Turton MD, O'Shea D, Gunn I, Beak SA, Edwards CM, Meeran K, Choi SJ, Taylor GM, Heath MM, Lambert PD, Wilding JP, Smith DM, Ghatei MA, Herbert J, Bloom SR (1996) A role for glucagon-like peptide-1 in the central regulation of feeding. Nature 379:69-72. CrossRef Medline

Vaswani K, Tejwani GA, Mousa S (1983) Stress induced differential intake of various diets and water by rat: the role of the opiate system. Life Sci 32:1983-1996. CrossRef Medline

Wang T, Edwards GL, Baile CA (1998) Glucagon-like peptide-1 (7-36) amide administered into the third cerebroventricle inhibits water intake in rats. Proc Soc Exp Biol Med 219:85-91. CrossRef Medline

Williams DL, Baskin DG, Schwartz MW (2009) Evidence that intestinal glucagon-like peptide-1 plays a physiological role in satiety. Endocrinology 150:1680-1687. CrossRef Medline

Yamamoto H, Lee CE, Marcus JN, Williams TD, Overton JM, Lopez ME, Hollenberg AN, Baggio L, Saper CB, Drucker DJ, Elmquist JK (2002) Glucagon-like peptide-1 receptor stimulation increases blood pressure and heart rate and activates autonomic regulatory neurons. J Clin Invest 110:43-52. CrossRef Medline

Yu YL, Lu SS, Yu S, Liu YC, Wang P, Xie L, Wang GJ, Liu XD (2009) Huanglian-jie-du-decoction modulates glucagon-like peptide-1 secretion in diabetic rats. J Ethnopharmacol 124:444-449. CrossRef Medline 